\title{
SUPPLY RESPONSE ANALYSIS OF INDONESIAN COCOA
}

\author{
Novi Rosilawati ${ }^{1) ;}$ Ketut Sukiyono2); Sriyoto2); \\ 1)Study Program of Agribusiness Magister Faculty of Agriculture, \\ University of Bengkulu \\ 2) Department of Agricultural Socio-Economics, Faculty of Agriculture, University of \\ Bengkulu \\ Email: ${ }^{1)}$ novirosi82@gmail.com; ${ }^{2)}$ ksukiyono@unib.ac.id
}

\begin{abstract}
How to Cite :
Rosilawati, N., K Sukiyono, Sriyoto, 2019. Supply Response Analysis of Indonesian Cocoa. Journal of Agri Socio-Economics and Business. 1 (1): 25-138 DOI: https://doi.org/10.31186/jaseb.1.1.25-38
\end{abstract}

\section{ARTICLE HISTORY}

Received [xx Month $x x x x]$

Revised [xx Month $x x x x$ ]

Accepted [xx Month $x x x x]$

\section{KEYWORDS}

supply response,

cocoa,

SURE,

elasticity 3 keyword

This is an open-access article under the $C C-B Y-S A$ license

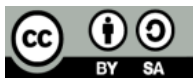

\section{ABSTRACT}

The Supply response of cocoa in Indonesia is done through an approach to the area of cocoa plantations, in response to economic factors and non-economic factors. Data analyzed from 1985 to 2015 (time series). The aim is to find out the factors that affect the area of cocoa plantations in Indonesia and the response of the offer of cocoa in Indonesia seen from the value of short-term elasticity and long-term elasticity. The partial adjustment and adaptive expectation model was applied and continued with an analysis of Seemingly Unrelated Regression Equations (SURE). The results of the analysis show that the factors affect the area of cocoa plantations in Indonesia are on smallholder plantations, namely coffee prices, rubber prices, and technology. In the state plantations, namely the previous year's cocoa plantation area, rubber prices, technology, and government policy. In private plantations, namely rubber prices, technology, and labor costs. Supply response of cocoa that is in line with the value of elasticity both short and long term is inelastic which means that it is following expectations, where the value of long-term elasticity is greater than the value of short-term elasticity. 


\section{INTRODUCTION}

The Plantation Sub-Sector is one of the largest sub-sectors in Indonesia. For the past five years, this subsector has contributed positively to Indonesia's trade balance. According to BPS data, in 2015 Indonesia's oil and gas trade balance was a deficit of US $\$ 6,038.8$ million, of which oil and gas exports amounted to US\$ $18,574.4$ million, and imports amounted to the US $\$ 24,613.2$ million. While the Non-Oil and Gas trade balance experienced a surplus of US $\$ 13,709.5$ million, of which exports amounted to US\$131,791.9 million with imports amounting to US\$ $118,082.4$ million. One promising plantation commodity in the international market is the cocoa commodity.

According to the ICCO (2014), the world cocoa market situation shows that Indonesia is expected to be the most dynamic country involved in processing activities. Half cocoa product exports are greater than cocoa bean exports while the growth of cocoa processing is estimated at $22 \%$ to 310,000 tons in the current season. Besides, the inadequate local supply of cocoa beans has limited the progress of the processing sector. To meet the increasing needs of cocoa in the country and fulfill foreign demands, the production should be increased and accelerated both by increasing cacao land area and productivity. However, cocoa production has experienced fluctuations which are in line with the fluctuations in the plantation area. Data from the Director-General of Plantation (2015) informed that the cacao area was 1,724,092 ha with a production of 661,234 tons. This area has increased by $1.18 \%$ per year since 2010 while production decreased by $3.15 \%$. The government has also considered removing cocoa import duties to facilitate the import of cocoa beans to meet growing domestic demand for the cocoa processing industry.

The discussion and data above show that various policies have been implemented for cocoa development in Indonesia. However, the data shows that the development of the area, cacao production and exports have fluctuated. This condition raises the question of what factors affect the development of the area, production, and export of cacao Indonesia. More specifically, how is the extent of the response of Indonesian cocoa producers to changes in economic and noneconomic variables? For these reasons, research aimed at determining economic and non-economic factors is profound to conduct.

Various researches have been conducted to analyze producer response on economic as well as non-economic variables. Among others are Sukiyono (1995) for palm oil, Saddiq, et al (2012) for sugar cane, Mehregan, et al (2013) for cotton, and Shahzad, et al (2018) for tobacco. They used a different model for analyzing the response of producers. Sukiyono used Nerlovian model to analyze palm oil producers in response to economic variable shocks, while Shahzad applied the Autoregressive Distributed Lag (ARDL) model for analyzing tobacco producer response. These facts indicate that various models can be applied to analyze supply response, especially for perennial crops. For this reason, this paper applies 
Nerlovian model to determine the factors that influence Cocoa supply in Indonesia and to examine cocoa producer response to economic and non-economic variables.

\section{RESEARCH METHODS}

\section{Method of Collecting Data}

This research uses secondary data types. The data analyzed for 31 years are time-series data from 1985 to 2015 sourced from the Ministry of Agriculture's, Agricultural Information System Data and other relevant agencies.

\section{Data Analysis Method}

\section{Empirical Model}

Cocoa supply response can be estimated by analyzing area response to variables that affect it. Supply response models for smallholder, state and private plantations follow closely to Sukiyono (1995) models. In this research, the Cacao area $\left(A_{t}^{D}\right)$ is assumed as a function of expectation of Cocoa prices $\left(P C_{t}^{e}\right)$, Cocoa acreage in the previous year $\left(A_{t-1}\right)$, Cocoa area two years earlier $\left(A_{t-2}\right)$, Coffee Prices in the previous year $\left(P K_{t-1}\right)$, Rubber Prices of the previous year $\left(P R_{t-1}\right)$, Urea fertilizer prices $\left(P P_{t}\right)$, labor wages $\left(L W_{t}\right)$, Technology $\left(T_{t}\right)$, Government policy dummy variables $\left(G_{t}\right)$ and the dummy variable of the Processing industry $\left(I_{t}\right)$. The long-term model of Indonesian Cocoa supply can be written as follows:

$$
\begin{aligned}
A_{t}^{D}= & \alpha_{0}+\alpha_{1} P C_{t}^{e}+\alpha_{2} P K_{t}^{e}+\alpha_{5} P R_{t-1}+\alpha_{6} P P_{t}+\alpha_{7} L W_{t}+\alpha_{8} T_{t}+\alpha_{9} G_{t}+ \\
& \alpha_{10} I_{t}+\mu_{t}
\end{aligned}
$$

In equation (1), the unobserved variable is $A_{t}^{D}$ and $P C_{t}^{e}$. The area of cocoa that is to be planted $\left(A_{t}^{D}\right)$ is the area that the farmer wants to plant in the period $\mathrm{t}$ by following the partial adjustment hypothesis. The partial adjustment hypothesis states that the actual change in the area planted is the proportion (h) of the change in the area to be added to the standard deviation. The partial adjustment hypothesis is written as follows:

$$
A-A_{t-1}=h\left(A_{t}^{D}-A_{t-1}\right)+\mu_{t}, \quad 0<\mathrm{h} \geq 1
$$

where: $A_{t}$ is actual area planted in Year $t, A_{t}^{D}$ is area to be planted in Year $t, h$ is adjustment coefficient.

Meanwhile, cacao price is assumed to follow the adaptive Expectation hypothesis. This hypothesis, introduced by Friedman (1957), states that the future price of cacao is solely dependent on its past values. The adaptive cacao price expectations hypothesis is formed by the following equation:

$$
P C_{t}^{e}-P C_{t-1}^{e}=b\left(P C_{t}-P C_{t-1}^{e}\right), \quad 0<b<1
$$


where: $P C_{t}^{e}$ is future expected cacao prices in year $\mathrm{t}, P C_{t-1}^{e}$ is expected the cocoa price at year $t-1, P C$ is actual current price, and $b$ is expectation coefficient,

By using simple algebra and repeated substitutions of equation (2) and (3) into equation (1), the long-term dynamic model for Indonesian Cocoa can be specified as follows:

$$
\begin{aligned}
A_{t}^{D}= & \alpha_{o} h+(1-h) A_{t-1}+\alpha_{1} h\left[b Z_{t}+b f_{o}(1-b)^{t}+\alpha_{2} h P K_{t-1}+\alpha_{3} h P R_{t-1}+\right. \\
& \alpha_{4} h P P_{t}+\alpha_{5} h L W_{t}+\alpha_{6} h T_{t}+\alpha_{6} h G_{t}+\alpha_{7} h I_{t}+\mu_{t} \\
A_{t}^{D}= & \alpha_{o} h+(1-h) A_{t-1}+\alpha_{1} h b_{1} Z_{t}+\alpha_{1} h b f_{o}(1-b)^{t}+\alpha_{2} h P K_{t-1}+\alpha_{3} h P R_{t-1}+ \\
& \alpha_{4} h P P_{t}+\alpha_{5} h L W_{t}+\alpha_{6} h T_{t}+\alpha_{7} h G_{t}+\alpha_{8} h I_{t}+\mu_{t}
\end{aligned}
$$

Or, equation (4) can be simplified as:

$$
\begin{gathered}
A_{t}^{D}=\gamma_{0}+(1-h) A_{t-1}+(1-h) A_{t-1}+\gamma_{1} Z_{t}+f_{d}(1-b)^{t}+\gamma_{2} P K_{t-1}+\gamma_{3} P R_{t-1}+ \\
\gamma_{4} P P_{t}+\gamma_{5} L W_{t}+\gamma_{6} T_{6}+\gamma_{7} G_{t}+\gamma_{8} I_{t}+\mu_{t}
\end{gathered}
$$

where: $\gamma_{0}=\alpha_{0} h, \quad \gamma_{1}=\alpha_{1} h b_{1} f_{d}=\alpha_{1} h b f_{o}, \quad \gamma_{2}=\alpha_{2} h, \gamma_{3}=\alpha_{3} h, \gamma_{4}=\alpha_{4} h$,

$$
\gamma_{5}=\alpha_{5} h, \gamma_{6}=\alpha_{6} h \cdot \gamma_{7}=\alpha_{7} h \gamma_{8}=\alpha_{8} h
$$

To estimate equation model (5), it will be formulated with the following steps: a) model of cacao producer will be estimated separately using maximum likelihood $(\mathrm{LM}) ; \mathrm{b})$ The value of $\mathrm{Zt}$ and $(1-b)^{t}$ by observing each value of $\mathrm{b}$, where $0<\mathrm{b} \leq 1$. Assuming the use of error is normally distributed and free by using LM estimation, to maximize the likelihood function the value of $b$ is located between 0.05 and 1.00 with 0.05 stages. Because parameter confounding error values from LM regression are biased so it must look for LM estimator interruption error values by following the Doran \& Griffiths (1978) suggestion to get asymptotic standard errors.; c) Models (smallholder plantations, large private plantations, large state plantations) will be estimated together using Seemingly Unrelated Regression Equations (SURE).

The SURE method was introduced by Zellner (1962), This SURE model is used because the model used by the variables that exist in each model is the same, because the variables used together are thought to have correlations between variables. By using the SURE model, the three models will be analyzed together, which will minimize the annoying errors. To estimate three supply response models of Cocoa producers, Estimated Generalized Least Square (EGLS) was used (see Sukiyono $(1995,2004)$ for detail). 


\section{RESULTS AND DISCUSSION}

\section{Results of Estimated Supply Response to Three Indonesian Cocoa Producers}

The estimation results using SURE analysis of the three models of Indonesian Cocoa plantations is presented in Table 1. The best model is selected based on existing LR value compared to its $\chi^{2}$ value. The LR 17.2220 value is greater than the chi-square value. i.e., 9.3484. According to Gujarati (2013), this implies that the model can be applied to analyze producer behavior in response to economic and non-economic incentives. Furthermore, SURE results are better than the results of separated estimation indicated by the higher $\mathrm{R}^{2}$ value of the SURE analysis. With the SURE approach, $\mathrm{R}^{2}$ is $0.9913,0.8971$, and 0.9584 for smallholder, state-owned, and private producers respectively while when the model is estimated separately, the $\mathrm{R}^{2}$ value is $98.58 \%, 88.81 \%$, and $89.71 \%$ respectively.

Table 1. SURE Results in Three Joint Cocoa Producers

\begin{tabular}{|c|c|c|c|}
\hline Parameter & Smallholder & State-Owned & Private \\
\hline Constant & $\begin{array}{c}12.172^{\star \star \star} \\
(1.62)\end{array}$ & $\begin{array}{c}10.396 * \star \\
(2.517)\end{array}$ & $\begin{array}{l}11.821 \text { *** } \\
(2.061)\end{array}$ \\
\hline$A_{t-1}$ & $\begin{array}{r}-0.0465 \\
(0.186)\end{array}$ & $\begin{array}{r}0.1602 * * \\
(0.086)\end{array}$ & $\begin{array}{l}0.1216 \\
(0.227)\end{array}$ \\
\hline$Z_{t}$ & $\begin{array}{r}-0.1288 \\
(0.065)\end{array}$ & $\begin{array}{r}-0.0567 \\
(0.029)\end{array}$ & $\begin{array}{l}0.0322 \\
(0.055)\end{array}$ \\
\hline$P K_{t-1}$ & $\begin{array}{c}-0.3387 * \star * \\
(0.097)\end{array}$ & $\begin{array}{r}-0.1514 \\
(0.101)\end{array}$ & $\begin{array}{l}0.0453 \\
(0.074)\end{array}$ \\
\hline$P R_{t-1}$ & $\begin{array}{l}0.3778 * * * \\
(0.062)\end{array}$ & $\begin{array}{c}0.3037 * * \\
(0.079)\end{array}$ & $\begin{array}{l}0.1706 * * \\
(0.063)\end{array}$ \\
\hline$P P_{t}$ & $\begin{array}{l}0.0593 \\
(0.056)\end{array}$ & $\begin{array}{r}-0.0248 \\
(0.084)\end{array}$ & $\begin{array}{r}-0.0624 \\
(0.059)\end{array}$ \\
\hline$L W_{t}$ & $\begin{array}{l}0.0685 \\
(0.085)\end{array}$ & $\begin{array}{l}0.1137 \\
(0.158)\end{array}$ & $\begin{array}{c}-0.1722 * \\
(0.097)\end{array}$ \\
\hline $\mathrm{T}$ & $\begin{array}{l}0.0768 * * * \\
(0.013)\end{array}$ & $\begin{array}{c}-0.1841 \text { * } \\
(0.068)\end{array}$ & $\begin{array}{r}-0.0749 * * \\
(0.034)\end{array}$ \\
\hline G & $\begin{array}{l}0.0335 \\
(0.099)\end{array}$ & $\begin{array}{c}0.3594 * \star \\
(0.173)\end{array}$ & $\begin{array}{l}0.0678 \\
(0.126)\end{array}$ \\
\hline 1 & $\begin{array}{l}0.0549 \\
(0.111)\end{array}$ & $\begin{array}{l}0.0983 \\
(0.183)\end{array}$ & $\begin{array}{r}0.1069 \\
(0.12)\end{array}$ \\
\hline$R^{2}$ & 0.9913 & 0.8971 & 0.9584 \\
\hline$\alpha^{2}$ & 3.591 & 10.12 & 3.668 \\
\hline LM & & 8.9693 & \\
\hline LR & & 17.2220 & \\
\hline$\chi_{1}^{2}$ & & 9.3484 & \\
\hline
\end{tabular}


Note : *** and *** is significant at the level 10\%, 5\% and $1 \%$. Values in parentheses indicate the standard asymptotic error.

The smallholder plantation model equation shows that the area in the previous year, the labor wages, the technology, government policy and the development of the cocoa industry have a sign as expected. Meanwhile, the expectations of Cocoa prices, rubber prices, and fertilizer prices have values, not in line with expectations. The partial adjustment coefficient of the desired area estimated by using the area coefficient value of the previous year and assuming that the proportion (h) is (1 - h), so the Partial Adjustment Hypothesis is as follows :

$$
A-A_{t-1}=1.21\left(A_{t}^{D}-A_{t-1}\right)
$$

To examine the expected price of Cocoa ( $\mathrm{Zt})$, namely by looking at the Cocoa price coefficient where the value is $b$, where the value of $b$ is $(1-b)$, so the Expectation Adaptation Hypothesis is as follows :

$$
P C_{t}^{e}-P C_{t-1}^{e}=1.13 \quad\left(P C_{t}-P C_{t-1}^{e}\right)
$$

The results of state plantation model equation show that the area in the previous year, coffee prices, fertilizer prices, labor wages, government policies and the development of the cocoa industry has an expected sign, except for Cocoa price expectations, rubber prices, and technology. Similar to the smallholder model, the partial adjustment coefficient of the desired area is also examined from the previous area coefficient value as follows:

$$
A-A_{t-1}=0.81 \quad\left(A_{t}^{D}-A_{t-1}\right)
$$

The Expectation Adaptation Hypothesis of cacao price is as follows :

$$
P C_{t}^{e}-P C_{t-1}^{e}=1.06 \quad\left(P C_{t}-P C_{t-1}^{e}\right)
$$

The estimation has also resulted in factors determined private plantation response to various economic and non-economic variables. These variables include model shows that the production previous coffee prices, rubber prices, technology, and labor wages while others are not. Using a similar process as state own and smallholder plantation, the partial adjustment coefficient of the desired area can be written as follows:

$$
A-A_{t-1}=\underset{(0.65)}{0.90}\left(A_{t}^{D}-A_{t-1}\right)
$$

While the Cacao price Expectation Adaptation Hypothesis is defined as follows:

$$
P C_{t}^{e}-P C_{t-1}^{e}=0.97 \quad\left(P C_{t}-P C_{t-1}^{e}\right)
$$




\section{Economic Interpretation of Results}

\section{Lag in Adjustment}

The level of adjustment in the area of smallholder cocoa can be calculated, where the previous year's lag area coefficient is -0.0465 , i.e.:

$$
\begin{aligned}
(1-h) & =-0.0465 \\
h= & 1-(-0.0465) \\
& =1.0465 \approx 1.05
\end{aligned}
$$

This means that the community cocoa plantation area can adjust 105 percent of the desired change in cocoa prices per year and other fixed variables/ceteris paribus. The length of time needed to adjust 95 percent of the desired area can be calculated as follows:

$$
\begin{aligned}
(1-h)^{N} & =(1-0.95) \\
(0.0465)^{N}= & 0.05 \\
N & =\log (0.05) / \log (0.0465) \\
& =0.9763 \approx 0.9 \text { year }
\end{aligned}
$$

The interpretation that smallholder cocoa plantations need 0.9 years in an area adjustment required 95 percent. In making smallholder plantation decisions faster because if there is a better opportunity to increase or reduce the area more quickly because the land owned is only privately owned so the decision to increase or reduce the plantation area is faster. Smallholder plantations processed by farmers, still not implementing the good agriculture practice system, most farmers consider Cocoa plants as Annual fruit plants. This causes the resulting of low productivity, besides that Cocoa plants, take 2.5 - 3 years to produce and harvest age is only up to 11 years. So that if there is a more profitable commodity, the farmers will quickly decide to replace the planting area with other commodities. Considering that almost $90 \%$ of Cocoa production is produced from smallholder plantations, the government must provide a policy that can directly touch Cocoa farmers, this is intended to reduce the conversion of cocoa land into other plantation lands.

In smallholder plantations, an adjustment of 95\% of the plantation area was 0.9 years according to the facts in the field. Government policy in expanding plantation areas using plantation revitalization programs effectively increased the area of people's cocoa plantations, where the total area of people's cocoa plantations in 2006 was 1,219,633 ha to 1,682,008 in 2015.

Lag adjustment in the state plantation Cocoa area, with the same calculation. The results obtained indicate that the state cocoa plantation area can adjust 85 percent of the desired change in Cocoa prices per year and other variables ceteris paribus. The interpretation shows that state-owned cocoa plantations in an area require 95 percent in 17.2 years. State plantations have a very important role in maintaining stocks for export. The quality of Indonesian Cocoa is of good quality and is used as a mixture of other Cocoa. Maintaining plantations means maintaining the stability of Indonesian Cocoa exports, government intervention in 
maintaining trade balance stability between exports and imports, Cocoa production must be maintained.

Government policy has a significant effect on state-owned plantations in increasing plantation area, but data on existing state plantation area has decreased plantation area starting in 1999, meaning that the state cocoa plantation area is not following the field reality. The results of the calculation of the adjustment of $95 \%$ of the country's cocoa plantations amounted to 17.2 years according to the facts.

Lag adjustments in the cocoa area of private plantations, with the same calculation. The results obtained by interpretation are that the private cocoa plantation area can adjust 88 percent to the desired change in Cocoa prices per year and other variables ceteris paribus. The private cocoa plantation in the area of adjustment requires 95 percent in 23.1 years. Because private plantations have problems in getting new land for plantations. If private plantations want to increase the plantation area, they must apply for Cultivation Right (HGU), in accordance with Law Number 5 of 1960 concerning Basic Agrarian Principles in Article 28-30 which states that the Right to Cultivate is the right to cultivate land which directly controlled by the State (State Land) by Indonesian citizens or Indonesian legal entities, within a certain period of time for agricultural, fishery or livestock companies, which are at least 5 ha and require proper capital investment and good company techniques for an area of more than 25 ha, which is given a maximum period of 25 years or 35 years and at the request of the rights holder and considering the condition of the company can be extended for a maximum period of 25 years.

For the development of Cocoa plantations, a large investment is needed. If Cocoa plantations are not profitable, the land will be converted to commodities with high economic value but take a long time. Land adjustments when viewed from real data on the area of cocoa, smallholder plantations tend to decline every year starting in 1997 which is the year of the economic crisis that caused uncontrolled price fluctuations, especially plantation crops. Overall, the total area of private cocoa cultivation that takes 23.1 years to adjust to $95 \%$ of plantations is correct.

\section{Response to Cocoa Prices}

The coefficient of expectation of Cocoa prices on private plantations has a positive sign with an expectation value of 0.0322 . This informs that with a 1 percent increase in cocoa prices, the Cocoa area will increase by 0.0322 percent. In private estates, the price of cocoa plays an important role in developing, the orientation of private commercial plantations seeking profit. Prices will greatly affect the profits to be obtained, so the price of cocoa is very influential on private plantations.

The people's plantation coefficient is -0.1288 and state plantations are 0.0567 , this indicates that the hypothesis is rejected because the value of the 
coefficient of Cocoa prices is negative. Negative marks are not in line with expectations that with an increase in Cocoa prices it will affect the area of Cocoa plantations but on smallholder plantations and state-owned plantations, this does not happen.

Cocoa price expectations are not significant at the level of 10 percent in the three Cocoa producers. World cocoa prices are relatively stable at a high level because they often experience deficits in the world market. This causes the price of cocoa to be relatively high, but prices at the farm level are sometimes determined by traders who cause low farmer prices. With the low prices received by farmers, and the care needed by Cocoa plants is relatively intensive to produce good production, which causes farmers to be relatively easier to change to other commodities that have higher economic value. State plantations do not affect the expectations of Cocoa prices, because the state must maintain stock to maintain the stability of international trade in keeping the trade balance in surplus.

Own price elasticity of Cocoa area on smallholder plantations is inelastic in the short and long term. Where the value of short-term elasticity in smallholder plantations is -0.1288 which means that if there is an increase in price of 1 percent it will reduce the number of offers by 0.1288 percent and 0.0567 percent on state plantations and will increase the supply amount by 0.0322 percent on private plantations where other variables remain/cateris paribus.

According to Anindita and Baladina (2017) states that generally, the elasticity of plantation offers is inelastic because agricultural producers need a long time to adjust the level of production if there is a change. Offer elasticity is useful for forecasting the amount that will be offered in the future.

Table 2. Estimated Price Elasticity and Cross Elasticity of Cocoa Areas

\begin{tabular}{lccc}
\hline Elasticity & Smallholder & State & Private \\
\hline Own price elasticity & & & \\
$\quad$ Short term elasticity & -0.1288 & -0.0567 & 0.0322 \\
Long term elasticity & -0.1141 & -0.0537 & 0.0333 \\
\hline Cross elasticity to coffee price & & & \\
$\quad$ Short term elasticity & -0.3387 & -0.1514 & 0.0453 \\
Long term elasticity & -0.2530 & -0.1315 & 0.0474 \\
\hline Cross elasticity to rubber price & & & \\
$\quad$ Short term elasticity & 0.3778 & 0.3037 & 0.1706 \\
Long term elasticity & 0.6072 & 0.4362 & 0.2057 \\
\hline
\end{tabular}

\section{Response to Coffee Prices}

The coefficient value of coffee on smallholder estates of -0.3387 and state plantations of -0.1514 is negative, which means that coffee prices are in line with expectations, that every 1 percent increase in coffee prices will decrease the area 
of cocoa in smallholder plantations by 0.3387 percent and on state plantations fell by 0.1514 percent.

Coffee commodities are relatively easier to maintain when compared to Cocoa, besides that the diseases that exist in commodities Coffee is not at great risk of crop failure as in Cocoa. Thus, if the price of coffee increases it will affect the decline in the area of cocoa plantations.

On private plantations, the hypothesis is rejected because the Coffee price coefficient is positive at 0.0322 . Private plantations in response to prices of other commodities tend to be slower because the time needed to change plantation patterns requires large funds and the products produced also requires a long time, whereas in private plantations profit is the main thing in establishing plantations. Cross elasticity of coffee prices is inelastic both short and long term, wherein the value is inelastic following expectations. The elasticity value -0.3387 , which means that if an increase in coffee prices by 1 percent will reduce the number of cacao offerings by 0.3387 percent in the other variable fixed / cateris paribus in the short term on smallholder plantations and state plantations which will reduce supply by 0.1514 percent. But on private plantations will increase supply by 0.0453 percent in the short term.

\section{Response to Rubber Prices}

The coefficient value of the third rubber plantation has a positive value which means that the hypothesis is rejected. This shows that the increase in rubber prices is not significant for the area of cocoa plantations to be planted, but the price of rubber is very significant in responding economically. Plantations will tend to transfer land to rubber because rubber does not require intensive maintenance as in Cocoa, not based on rising prices prevailing in the market.

Cocoa price trends tend to be more stable, this will have a positive impact on plantations to maintain plantations. While the price of rubber tends to be more volatile, but the care needed is less when compared to Cocoa plants. According to Milz, Brant, Wijayanto, Afwandi, \& Terhorst (2016) Cocoa plants can be planted together with other plantation crops such as rubber and oil palm or timber plants.

The cross elasticity of rubber prices is inelastic both short and long term, wherein the value is inelastic following expectations. If an increase in rubber prices by 1 percent will increase the number of cacao offerings by 0.3778 percent on smallholdings, on state plantations it will increase by 0.3037 percent and 0.1706 percent on private plantations in the short term where other variables remain.

\section{Response to Fertilizer Prices}

The price of fertilizer is not significant at the level of 10 percent in the three producers / Cocoa plantations. The coefficient of fertilizer prices on state plantations is -0.0248 , which means that according to expectations if there is a rise in fertilizer prices increase by 1 percent, it will reduce the area of cocoa by 0.0248 
percent. The coefficient of private plantations amounting to -0.0624 that fertilizer prices are in line with expectations if an increase in fertilizer prices by 1 percent will reduce the supply of cocoa by 0.0624 percent. This is in line with the value of inelastic elasticity both short-term elasticity and long-term elasticity. State plantations and private plantations in the maintenance of plants are very concerned about the needs of plants, of course, this will affect the area of plantations to be planted.

In smallholder plantations, the value of the fertilizer price coefficient is 0.0593 which means it does not match expectations as indicated by the fertilizer price coefficient marked positive in line with the inelastic short and long term elasticity values. Because the behavior of smallholder plantations has not carried out planting according to the recommendations in increasing production so that the fertilizer provided is still far from the recommendations of researchers. Smallholder plantations will provide fertilizer if possible, the nature of smallholder plantations has little capital so that fertilizer purchases are not a major factor.

Table 3. The Elasticity of Short and Long Term Offers on Fertilizer Prices and Changes in Labor Wages

\begin{tabular}{cccc}
\hline Elasticity & $\begin{array}{c}\text { Smallholder } \\
\text { Plantations }\end{array}$ & State Plantations & $\begin{array}{c}\text { Private } \\
\text { Plantations }\end{array}$ \\
\hline $\begin{array}{c}\text { Fertility price elasticity } \\
\text { Short term elasticity }\end{array}$ & 0.0593 & -0.0248 & -0.0624 \\
Long term elasticity & 0.0630 & -0.0242 & -0.0587 \\
\hline Labor wage elasticity & & & \\
Short term elasticity & 0.0685 & 0.1137 & -0.1722 \\
Long term elasticity & 0.0735 & 0.1283 & -0.1469 \\
\hline
\end{tabular}

\section{Response to Labor Wages}

The coefficient of labor wages on smallholder plantations is 0.0685 and state plantations are 0.1137 which means it is not in line with expectations because the coefficient value is positive and not significant at the 10 percent level. Where the value of short-term and long-term elasticity is inelastic, which means that if a $1 \%$ increase in labor wages will reduce the number of bids by 0.0685 percent on smallholders and 0.1137 percent on state plantations in the short term. In smallholder plantations and state plantations, the labor force spent is mostly a labor of plantation owners and uses little labor outside, so that if no increase in labor wages do not affect.

In contrast to private plantations, labor wages greatly affect private plantations where the labor wage coefficient is negative at -0.1722 , if there is an increase in labor wages of 1 percent it will reduce the area of Cocoa by 0.1722 percent, in line with the value of short-term elasticity which means if there is a 1 percent increase in labor wages, it will reduce the number of offers by 0.1722 
percent. The value of short-term and long-term elasticity that is inelastic means that the supply response to wages of labor does not respond quickly because plantation crops need a long grace period.

\section{Response to Technology}

The trend of technological change in smallholder estates has a positive coefficient value of 0.0768 which means that it is in line with expectations. If the technology used increases by 1 percent, the area of Cocoa will increase by 0.0768 percent. This shows that technological changes significantly affect the area of plantations to be planted because smallholder plantations that only carry out plantations are not yet in line with the recommendations, if there are new technologies and touch directly on community plantations it will increase the area of smallholder cocoa plantations.

On state plantations, the technology coefficient of -0.1841 is not in line with expectations. Private plantations with a coefficient value of -0.0749 with a negative sign do not match expectations. Technology does not affect the area of state and private plantations, because these plantations have planted according to recommendations that will increase production.

\section{Response to Government Policy}

Government policies in the plantation sector show behavior following expectations, that is positive. This means that policies issued by the government will tend to affect the area of cocoa plantations.

The revitalization program aims to accelerate the development of smallholder plantations through cocoa renewal, expansion and rehabilitation activities. This policy uses the people's core and plasma pattern approach by involving plantation companies with farmers. With a program that touches farmers directly, it will have a positive impact on the development of the Cocoa plantation area.

\section{Response to the Development of the Indonesian Cocoa Industry}

The coefficient value of the development of the Cocoa industry on smallholder plantations, state plantations, and private plantations is positively marked which shows that by developing the Cocoa industry it will tend to affect the area of Cocoa plantations in meeting the demand for industrial Cocoa as raw material. This means that Cocoa offers will increase every year. If the Cocoa industry in the country develops and takes raw materials from within the country it will provide an opportunity for Cocoa plantations to carry out continuous production. 


\section{CONCLUSIONS AND RECOMMENDATIONS}

\section{CONCLUSIONS}

Factors affecting the area of cocoa plantations in Indonesia are namely on smallholder plantations, coffee prices, rubber prices, and technology. On state plantations, namely the previous year's cocoa plantation area, rubber prices, technology, and government policies had an influence. On private plantations, namely rubber prices, technology and labor costs. The response to the offer of cocoa which is in line with the value of elasticity both short and long term is inelastic which means that it is following expectations, where the value of longterm elasticity is greater than the value of short-term elasticity.

\section{RECOMMENDATIONS}

Government policies that do not match the analysis and reality in the field, to be further studied in future research. Increased productivity and rainfall can be included as factors that influence the response of cocoa supply in Indonesia.

\section{REFERENCES}

Anindita, R dan Baladina, N. 2017.Pemasaran Produk Pertanian. ANDI. Yogyakarta (hal: 41-55).

Doran, H.E. \& Griffiths, W.E. 1978. Inconsistency of the O.L.S. estimator of the partial adjustment-adaptive expectations model. Journal of Econometries 7: 133-46.

Gujarati dan Porter. 2013. Dasar-Dasar Ekonometrika Edisi 5-Buku I. Salemba Empat. Jakarta.

Mehregan, Keramatzadeh, Eshraghy, dan Bidabadi. 2013. Estimating the Response Cultivation Model of Cotton in Golestan Province of Iran. International Journal of Agriculture and Crop Sciences. IJACS/2013/6-17/1194-1198 ISSN 2227-670X (c2013 IJACS Journal. Available online at www.ijagcs.com (22 November 2016).

Milz, Brant, Wijayanto, Afwandi, \&Terhorst. 2016. Pengelolaan Kebun Kakao Berkelanjutan. GIZ GmbH FORCLIME. Jakarta.

Nerlove, M. 1956. Estimates of the Elasticities of Supply of Selected Agricultural Commocities. Journal of Farm Economocs, Vol.38, No.02 (May, 1956), 496 -509. https://msu.edu/course/aec/845/READINGS/Nerlove1956.pdf (22 November 2016).

Saddiq,M., Fayaz,M., Hussain,Z., \& Shahab,M. 2012. Acreage Response of Sugarcane to Price and Non Price Factors in Khyber Pakhtunkhwa. International Journal of Food and Agriculture Economics. Vol.2 No.3 pp.121-128.

Shahzad, Muhammad, Abbas Ullah Jan, Shahid Ali, RazaUllah. 2018. Supply Response Analysis Of Tobacco Growers In Khyber Pakhtunkhwa: An ARDL 
p-ISSN: 2685-7243

approach. Field Crops Research 218: 195-200. https://doi.org/10.1016/j.fcr.2018.01.004

Stastistik Perkebunan Indonesia 2014-2016 Kakao. http://ditjenbun.pertanian.go.id/tinymcpuk/gambar/file/statistik/2016/KA KAO\%202014-2016.pdf (23 Oktober 2016).

Sukiyono, K. 1995. PIR/NES Respon Penawaran Produsen Kelapan Sawit di Indonesia. Jurnal Penelitian Kelapa Sawit, 1995, 3(2) : 163 - 190.

Sukiyono, K. 2004. A Literature Riview on Supply Response of Parennial Crops.Agrisep Vol. 3 No. 1, September 2004 : 15 - 34.

Zellner, A., 1962, An efficient method of estimating seemingly unrelated regression equations and tests for aggregation bias, Journal of the American Statistical Association 57,348-368.

38 | Novi Rosilawati; Ketut Sukiyono; Sriyoto; Supply Response Analysis... 